\title{
Islamic Canon law encounters South African financing and banking institutions: Prospects and possibilities for Islamic economic empowerment and Black Economic Empowerment in a Democratic South Africa ${ }^{1}$
}

\author{
NATHIERA ABDULLAH \\ Lecturer, Faculty of Law, University of the Western Cape
}

\section{INTRODUCTION}

South Africa's government is committed to deracialising the economy and empowering the broader South African population. This type of economic and social reconstructionist philosophy is solidly based upon the Freedom Charter $^{2}$ that espouses the principle of the sharing and empowering society as a whole, and not just certain privileged racial or social groups, as was previously practised by the apartheid regime. It was never the intention of the present government that the economy should merely change from the previously entrenched economic empowered class (that formerly occupied dominant positions within an apartheid-driven economy) to an emerging previously disadvantaged economic dominant class assuming the same roles (to the exclusion of others) within a democratic South Africa. This would simply be the mere switching of hands of an economy that has failed to undergo any radical systemic transformation in an era which demands the ongoing democratisation of its previously segregated and exclusionist social institutions. The inclusion of a privileged few formerly disadvantaged South Africans would simply not be enough to successfully reverse the devastating effects the apartheid legacy had bequeathed to the majority of historically disadvantaged South Africans.

In fact, we need not look very far to see that we are still furiously struggling and dangerously grappling with this backlog of systematised economic impoverishment and under-development of the historically disadvantaged majority, even though we have managed to successfully wade through unknown and treacherous waters of economic reconstruction and development during the

\footnotetext{
1 This article is a reworked version of a paper presented on 17 October 2005 at a Legal Seminar at the South African Reserve Bank, Pretoria, South Africa.

2 The Freedom Charter, adopted at the Congress of the People, Kliptown on 26 June 1955.
} 
last fifteen years. The cumulative accolades of the present political, social and economic progress thus far is clearly not enough to quiet the ever-growing voice of those who are still dis-empowered (and daily struggling with its devastating economic effects like poverty, crime, inadequate basic facilities, illiteracy, sickness, etc.) by the legacy of apartheid. Much more is needed than simply window dressing or mere symbolic adherence to the tenants of the Freedom Charter. A clear and systematic effort has to be made and sustained if government wants to redress this great economic backlog. In principle this appears to be the most appropriate and logical course of action for the authorities to embark upon, yet such a course is beset with doubt and difficulties, because South Africa has no precedent by which it may gauge or bench-mark its current actual or contextual experience.

The strategy of Black Economic Empowerment (BEE) is one such possible vehicle for delivering a more equitable and economic just solution to the majority of South Africans who must share in the country's economy, as well as benefit from it. One of the most difficult problems surrounding Black Economic Empowerment (BEE) is the implementation of timeous service delivery. This problem is further exacerbated by the red tape which does not appear to be easy to unravel, especially if one thinks about the criteria ${ }^{3}$ which the poor must meet, in order to substantially benefit from BEE.

There is no doubt in the minds of the underprivileged and poverty stricken class that it is taking place at too slow a pace to be of any immediate (let alone medium or long-term) help to those who have to bear the brunt of encountering rejection from financial and banking institutions, and face the battle of starvation, inadequate funding and unemployment. The writing is on the wall and it appears as if the formerly advantaged economic dominant class is not doing enough to systematically implement Black Economic Empowerment (BEE), in order to realise the desired outcomes of a more equitable distribution of the accumulated spoils acquired during the era of the apartheid economy, in order to level out the economic playing field.

This is the major problem that South Africa is trying to resolve, and should become the focal point of its economic ventures and discussions if it is serious about redressing the economic injustices of the past, in order to meet all the basic needs of all its people.

\section{BROAD-BASED BLACK ECONOMIC EMPOWERMENT (BEE) AND ISLAMIC ECONOMIC EMPOWERMENT (IEE)}

The period following the 1994 democratic elections has been marked by a broad range of state policy, strategies and programme interventions which have been launched to not only overcome past inequities, but to creatively eradicate entrenched poverty. The underlying emphasis of these programmes was twofold: (1) the dismantling of apartheid and, (2) the transformation and stabilising of the country's economy.

3 S 12 of the Broad-Based Black Economic Empowerment Act No 53 of 2003, the Financial Sector Charter. 
The Constitution ${ }^{4}$ of South Africa is a witness to the same, in which the rights of all South Africans (i.e. the majority of citizens who were formerly denied this privilege) to equality are protected. Specific measures were implemented in order to redress the historical imbalances of the country's apartheid past within the economy, justice, health, education, arts, and so forth. Various other broad economic programmes like the Reconstruction and Development Programme (RDP) ${ }^{5}$ and Growth, Employment and Redistribution strategy (GEAR) ${ }^{6}$ have also been implemented subsequently to eradicate entrenched racial or ethnic and gender inequality as well as economic and wealth disparities through systemic and focused policies and praxis of Black Economic Empowerment (BEE).

From the above-mentioned discussion it is evident that government wants to implement these economic reconstructionist programmes within a context that embraces a broader strategy. This broad based empowerment programme was slowed down for a long time (from 1994-1998) by the low levels of initial capital endowment channelled to the previously disadvantaged business community. Thus there appeared to be a limited success rate with regards to the systematic implementation of BEE, and the envisaged number or target of previously disadvantaged South Africans (along with their historically advantaged counterparts) who would be co-owning, controlling and managing significant or major parts of the emergent transforming economy was quite disappointing. ${ }^{7}$

Along with this initial lagging period of transition, the BEE programme also had to contend with many unforeseen difficulties, such as high functional costs and legal fees, which left the new owners of most BEE companies with exorbitant debts and overheads, which were further problematised by the considerable economic volatility experienced globally during 1997-1998.

If one further studies the course trajectory of BEE developmental history, it also becomes clear that the periods from 1994-1997 and 1998-2002 were by far the most difficult formational phases in South African economic history for the successful programmatic implementation of BEE. Yet that does not mean that this time was of no value, nor that it had any significant impact on future thinking and planning of a broad-based BEE strategy for 2003-2014 (which many economist or entrepreneurs see as the time-frame to consolidate BEE strategies, initiatives and its envisaged long-term gains). From the current debates on BEE in terms of its programmatic implementation it has become clear that the BEE strategy must be defined in a more nuanced fashion, if optimal empowerment and developmental results are to be adequately harvested in the future. Government has taken the lead in this regard and

4 The Constitution of the Republic of South Africa, 1996.

5 The Reconstruction and Development Programme was the result of many months of consultation within the African National Congress, its Alliance partners and other mass organizations in the wider civil society.

6 A strategy for rebuilding and restructuring the economy in keeping with the goals set in the Reconstruction and Development Programme.

7 Information obtained through confidential interviews with selected companies and financial institutions. 
has formulated a clear and unambiguous definition of empowerment. One has only to consider some of the legislative documentation that relates to broad-based BEE to see the determination of government to de-racialise and transform the current state of the South African economy.

Some of these policies and statutes which testify to this phenomenal legislative endeavour aimed solely at creating a conducive economic developmental and reconstructionist environment and atmosphere are: The Promotion of Equality and Prevention of Unfair Discrimination Act, Extension of Security of Tenure Act, Restitution of Land Rights Act, Employment Equity Act, National Empowerment Fund Act, Competition Act, Telecommunications Act, Preferential Procurement Policy Framework Act, Minerals and Petroleum Development Act, ${ }^{8}$ the Financial Sector Charter, ${ }^{9}$ section 38 of the Companies Act No. 61 of 1973, as amended. ${ }^{10}$

All these efforts by government were to kick-start, facilitate, monitor and sustain a viable programme of accelerated and shared economic growth, in order to actively eradicate the historical problem of poverty and under-development of the historically disadvantaged in a fledgling democratic South Africa.

In order for the BEE strategy to be successful, government has chosen to focus upon four key principles:

- It had to be broad-based

- It had to be an inclusive programme

- It had to be associated with good governance, and

- It had to form an integral part of overall economic growth.

Thus, sustained economic growth and development in a democratic South Africa must affirm the government's broad-based BEE programme. ${ }^{11}$

One can also rephrase this statement in a more novel way by arguing that BEE was not intended to be an interesting addition or exotic appendage of the emergent transforming and developing South African economy, it had to be understood and utilised as an integral component of a powerful transformative economic engine. Therefore, it had to be broad-based and inclusive and not exclusive in terms of structure, form and nature, for no meaningful vehicle of economic growth and development seeking to re-dress the imbalances and inequities of South Africa's apartheid past could successfully flourish by excluding the historical disadvantaged majority from the same. BEE is then an integrative vehicle or economic paradigm (or systematic approach) that

8 Promotion of Equality and Prevention of Unfair Discrimination Act 4 of 2000, Extension of Security of Tenure Act 62 of 1997; Restitution of Land Rights Act 22 of 1994; Employment Equity Act 55 of 1998, National Empowerment Fund Act 105 of 1998; Competition Act 89 of 1998, Telecommunications Act 103 of 1996; Preferential Procurement Policy Framework Act 52000 and Minerals and Petroleum Development Act 28 of 2002.

9 In August 2002 at the NEDLAC Financial Sector Summit, the financial sector committed itself to the development of a Black Economic Empowerment Charter.

10 Section 9 of the Amendment Act No. 24 of 2006; commencement date 13th December 2007.

11 Broad-Based Black Economic Empowerment (fn 3 above) commencement date 21 April 2004. 
is associated with sustained economic growth and inclusive development of all South Africans, and not merely the piece-meal redistribution of accumulated pockets or enclaves of the county's formerly restricted existing wealth. Anything short of this will be a return to a racialised economy which is not only unconstitutional, but out of step with the political, social and economic development and stability of a democratic South Africa.

South Africa must look at ways in which it can increase the culture of investment, so that inclusive economic transformation and development can be realised on all levels for all South Africans, especially those who have been historically disadvantaged in a systematic way by the former apartheid economic policies and practices. At another level the country must also look to a broad economic front which includes other forms of developmental investment and developmental paradigms which can accelerate and enhance the practical and noble aims of government's BEE programme. Islamic Economic Empowerment or IEE could be such a transformative and developmental economic paradigm or model which could be utilsed in a collaborative fashion. ${ }^{12}$

\section{POSSIBILITIES IN TERMS OF AN EXPOSE OF ISLAMIC ECONOMIC EMPOWERMENT (IEE)}

Islamic Economic Empowerment or IEE, which is founded upon Islamic Canon Law or Shariah, could act as a catalyst for promoting accelerated and shared economic growth in the course and scope of the government's broad BEE programme for all South Africans. The teachings and practice of socio-economic justice and equitable distribution of accumulated income and wealth must be regarded as an important cornerstone in Islamic ethical and economic philosophy..$^{13}$ This forms a major part of the Islamic economic empowerment thinking ${ }^{14}$ and is founded upon the idea that humanity is regarded as a trustee who must strive to realise the ideals of socio-economic justice and general well-being in the world for all people an not just Muslims. ${ }^{15}$ In other words economic empowerment and development must not only become a mere watchword of adherents who elect to embrace the religion of Islam within a confined or parochial sphere, but must creatively and programmatically be effected on all levels of societal living and existence for the benefit and goodwill of all humanity. A sporadic or piece-meal economic empowerment and development strategy will not suffice in terms of stringent requirements of Islamic Canon Law or Shariah compliant thinking with regards to ongoing economic empowerment and development. In fact, Muslims are specifically called or mandated in terms of their unique Islamic Economic Empowerment (IEE) 'vocation' or 'mission' (i.e. da'wah), to be in solidarity and alliance-

12 Ahmad K Studies in Islamic Economics (ed) (1980) Jeddah.

13 Consult the study of Chapra M U "The Economic System of Islam - A Discussion of its Goals and Nature" (1979) London.

14 Mawdudi S A A "Economic and Political Teachings of the Qur'an" in Sharif M M (ed.) A History of Muslim Philosophy (ed) (1963) 179 - 190 Wiesbaden Germany.

15 Ahmad S M "Man and Money" (1970) Islamic Studies 217-244 Islamabad. 
"kinship" with the rest of struggling humanity, whichever part of the globe the economically distressed human family might find themselves in. ${ }^{16}$

From the afore-mentioned it is clear that Muslims are not called to only share in the resources, spoils and wealth of their countries and the world, but they are also urged to partake in its burdens and problems in terms of economic empowerment and development. This kind of economic mandate elevates the concept of Islamic Economic Empowerment (IEE) to a permanent and systematic vocation which is obligatory for all Muslims to diligently pursue its goals within the course of their daily lives and practice. ${ }^{17}$ This pervasive IEE philosophy embraces all facets of economic, social, political, ethical and spiritual life that Muslims encounter in the world which they find themselves co-habiting with the rest of humanity. IEE therefore cannot then be implemented in isolation or to the exclusion of the rest of humanity. ${ }^{18}$ The aims of IEE must be contextualised and implemented within a local and global ambit, in order for it to be congruent with the demanding requirements and compliances of Islamic Canon Law or Shariah. ${ }^{19}$ Nothing less than this will do to faithfully apply the strict and unambiguous injunction that IEE must be aimed at the total satisfaction of the essential human needs (not wants) and development, ${ }^{20}$ in order to attain a state of general well-being for all peoples who inhabit the world. ${ }^{21}$ Thus, it is imperative for those who strive to implement Islamic economic empowerment and development to utilse all legitimate means at its disposal, so that all the Shariah or Islamic Canon Law compliant goals, especially as it pertains to IEE might be realised. The trustees of Islamic Economic Empowerment (IEE) programmes must also judiciously use their available resources only for economic ventures which qualify for placement within the category of essential human needs and development. Anything outside the course and scope of human needs and well-being would not be deemed as being economically just or ethical, and would be classified as being un-Islamic and not complying with Islamic Canon Law or Shariah requirements.

IEE must then be aimed at the overall betterment of humanity's plight through the re-distribution of scarce economic resources which have been unevenly distributed, especially to those who are still caught up in the daily

16 Ahmad K "Economic Development in an Islamic Framework" as in Ahmad K Studies in Islamic Economics (ed.) (1980) 171 - 188 Jeddah.

17 Mintjies H Social Justice in Islam Amsterdam (1977); Mintjies H "The Shariah and Social Justice" (1977) in al-Mushir (April/June) 99-105 Rawalpinde, Mische G, P 'Toward a Humane World Order' (1977) New York.

18 Mannan M A Islamic Economics, Theory and Practice (1982) Lahore.

19 Zarqa M A "Islamic Economics: An approach to Human Welfare" in Ahmad K (ed)(1980) 3-18 Studies in Islamic Economics: Jeddah Nasr S H "Islam and the Plight of Modern Man" (1975) London for an interesting perspective on the matter of solidarity within a global context.

20 Abdur Ra'uf M “Islam and contemporary economic systems" (1976) MSA Contemporary Aspects of Economic Thinking in Islam Indiana USA 55-59.

21 Kahf M The Islamic Economy: Analytical Study of the Functioning of the Islamic System Indiana USA (1978). 
life and death struggle against poverty, disease, crime and underdevelopment. $^{22}$

In the South African context the immediate goals of IEE would be to eradicate poverty, economic stagnation and unemployment. ${ }^{23}$ These challenges affecting the economic and social well-being of the majority of formerly historically disadvantaged South Africans could be effected by implementing a three tier Islamic Economic Empowerment (IEE) structure or paradigm:

- Zakah: a regular programme of charity funded by way of obligatory taxation;

- Sadaqah: a regular programme of alms funded by voluntary contributions; and

- infaq fi sabil Allah: an additional programme for economic empowerment and social development funded by voluntary financing and investment in "the cause of Allah".

All three economic empowerment vehicles or strategies are aimed at promoting the circulation of wealth so that it does not become stagnant on account of unjust hoarding by a privileged or economically advantaged elite, as well as facilitating access to the same, in order that economic empowerment and development might filter down to all levels in society. ${ }^{24}$

The economic life and well-being of society depends mostly on the exchange of goods, products and services. Due to the inaccessibility and slowing down of finance (money in circulation), the smooth running of this vital exchange business is blocked or paralysed. This state of affairs eventually has a devastating effect on a country's economy, especially in the field of employment and the creation of sustainable employment. ${ }^{25}$ One only has to think of the many unemployed people who are unable to fulfil even their basic or essential life-needs, because they are not able to procure employment. ${ }^{26}$. Thus, the opportunity to acquire resources or funds needed to buy essential products or services are blocked or restricted. Zakah and Sadaqah would then serve as the first level of economic empowerment strategies that can be implemented to help remedy the crisis situation experienced by those who are in dire need of capital resources. These types of financial assistance strategies would be highly effective during the primary and medium phases of economic intervention, especially in situations where the recipients, who hail from the historically disadvantaged ranks, have no immediate security or collateral to secure the necessary loan from a bank or financial institu-

22 Ahmad S M "Social Justice in Islam" Lahore (1975) for an interesting discussion on economic justice and the social obligations of Muslims towards society at large.

23 Badawi M A Z "Zakat and Social Justice" in Islamic Council of Europe" as in The Muslim World and the Future Economic Order (1979) 112-122 London.

24 Abu S A H "The Theory of the Economics of Islam: The Economics of Tawhid and Brotherhood" as in 9-54 in MSA Contemporary Aspects of Economic Thinking in Islam (1976) Indiana USA 55-59.

25 Galbraith K Economics in Perspective London (1979); Galbraith K The Nature of Mass Poverty London (1979).

26 Naqvi S N H Ethics and Economics: An Islamic Synthesis UK (1981); Naqvi S N H "Economics of Human Rights: An Islamic Perspective" (1981) Hamdard Islamicus 47-61; Karachi Pakistan for an insightful discussion on this matter. 
tion. On another level Zakah and Sadaqah would also be utilised to assist the poor, destitute, orphaned, widowed, refugees, students, pilgrims, veteran soldiers, sick, exiled and any persons in society who are in a economically disempowered status, regardless of the reasons therefore, in terms of fulfilling their basic immediate and essential needs. ${ }^{27}$ In non-Islamic countries Zakah and Sadaqah are administered by the individual adherent, mosques or Islamic Community Organisations (ICOs) (e.g. the National Zakah Fund, etc.), whereas in Islamic countries these empowerment vehicles are usually administered by the government through the National Revenue Services. ${ }^{28}$ With Zakah and Sadaqah there is no flexibility in terms of investing these allocated funds for any given period in a bank or financial institution for capital development and growth. These funds are earmarked for immediate distribution and circulation among those who are in need, without any obligations of loan repayment from the recipient or profit- sharing allotted to the giver of Zakah and Sadaqah in return for the "investment".

The infaq fi sabil Allah option offers more promise, especially in terms of investment and programmatic economic development. This IEE financial vehicle or paradigm can be employed for short, medium and long term economic empowerment projects.

Unlike the Zakah and Sadaqah empowerment strategies which cannot be utilised for profit making and profit sharing purposes, the infaq fi sabil Allah can be meaningfully employed to realise these goals. Profit sharing financial or investment practices can also serve as a viable existent Islamic economic empowerment tool (available to all South Africans, not just Muslims) for instituting many of the aims of the government's broad based Black Economic Empowerment (BEE) policies and practices. This particular empowerment paradigm has already been in existence for a very long time in Islamic countries, and has now been contextualised with great success in other non-Islamic countries. ${ }^{29}$ Profit sharing economic empowerment strategies enable the formerly historically disadvantaged to have direct access to finance, goods and services that are necessary for reversing the dangerous tide of systematic economic and political dis-empowerment which destroyed the potential economic bases of the majority of South Africans living under the apartheid system. Now they can have a way of attaining the much needed financial and investment capital assistance without the onus of having to repay exorbitant amounts of interest or Ribah, as well as not having to bear all the risk associated with the entrepreneurial venture they intend to embark upon, especially if the economic venture fails or does not deliver the envisaged profits. In IEE strategies like profit-sharing oriented projects, the financier and the borrower share in the profits as agreed before-hand, as well

27 Yusuf S M Economic Justice in Islam New Delhi and Zaman, S M H Economic Functions of an Islamic State' London (1988).

28 Sakr M A "The Role of the State in the Economic System of Islam" (1980) Islam and a New International Economic Order: The Social Dimension, Geneva 103-110.

29 Badawi M A Z "Zakat and Social Justice", in Islamic Council of Europe, The Muslim World and the Future of Economic Order' London (1987). Galbraith K Economics in Perspective London (1987). 
as the associative risks that might accompany the intended business venture. One of the problems of implementing BEE has been the problem of access to financial resources and services, especially if the candidates are not able to furnish the necessary collateral to the banking and financial institutions. IEE investment strategies like Profit and Loss Sharing modes of financing such as. Mudarabah "commenda" or Islamic investment funds and Musharaka "partnership" or participating financing ${ }^{30}$ can be used to smooth the path for prospective entrepreneurs who would not qualify for financial and loan services because of the afore-mentioned. ${ }^{31}$

A further plus to this kind of IEE modes of financing is that it has to strictly adhere to Islamic Canon Law or Shariah compliant requirements for the permissibility and legitimacy of the financial investment or partnership, so that there is a built-in control and checking system for both parties. In this way, no partner can be exploited or made to adhere to unreasonable of non-compliant Islamic Canon Law or Shariah compliant practices. The Mudarabah mode of IEE financing can also be termed as a limited partnership existing between two or more parties, depending on the nature of the enterprise or the number of role players needed for the viability and success of the intended economic venture, ranging from a partnership between a finance company and a local fishing community, or a partnership between a financier and an entrepreneur who needs an outlay of capital to import sewing machines or spare parts. The key principles of this kind of investment and development model ( Mudarabah) are ones which are based on the idea of profit-sharing or/and losses, as well as the partnership being strictly compliant with specific Shariah or Islamic Canon Law requirements, such as that no interest or Riba can be charged by the funding partner for the capital provided.

In the case of the intended Mudarabah economic venture suffering a loss, the entire loss has to be carried by the financing partner. The entrepreneurial or managing partner is not required to re-imburse the same, but he/she must forego any form of remuneration for the expertise or services rendered during the venture. Here both parties are sharing in the risks and losses associated with the economic venture they elect to embark upon. On the other hand, if the venture is a success they share in the profits at a rate which they have mutually agreed upon beforehand, for example, the financing partner might receive $60 \%$ and the entrepreneurial $40 \%$ or any other percentage initially determined. The Mudarabah type of partnership is ideal for promoting broad BEE aims and philosophy, especially for Muslims, and other interested parties, who have the necessary surplus capital and are desirous of contributing to the economic empowerment and development of the formerly disadvantaged majority in our country. This kind IEE model can be made available to entrepreneurs on a variety of levels including SMMEs or bigger kinds of economic ventures, such as fish canning factories or joint seafaring vessel owners.

30 Nabil A Saleh (1986) Unlawful Gain and Legitimate Profit in Islamic Law. Riba, Gharar and Islamic Banking Chapter 4 'A financial system based on Islamic Ethics'.

31 Patel M A Mudarabah Karachi (1981) for an extended discussion in this regard. 


\section{CONCLUSION}

Presently Shariah-compliant financial products offered by South African banks with regard to banking products and investment products include savings accounts and current accounts; home, vehicle and business financing; equity funds, property funds, structured income funds and pension funds. ${ }^{32}$ Asset managers, the likes of Stanlib, Futuregrowth (in a joint venture with Albarak Bank Limited to manage the Futuregrowth Albaraka Equity Fund, a Shariah-compliant unit trust), Oasis and Fraters ${ }^{33}$ have also aggressively entered this market. Against this backdrop the suggestion of the three-tiered IEE paradigm or structure is a rather inimitable one. There is no comparative study to draw from in order to assess the real impact or effect that the implementation of the IEE model of financing could have on the South African economy.

South African banks, asset managers, Zakat trusts ${ }^{34}$ and other finance institutions could find creative ways of accessing Muslims (or other interested parties) who are interested in financing or investing in economically viable IEE projects and ventures, by developing innovative Shariah-compliant financial and investment products. In this way they will not only be contributing to the government's broad-based BEE programme and philosophy, but also to the ongoing development of the country's stability and prosperity through nurturing a culture of economic development and investment via IEE strategies within the course and scope of BEE.

\section{BIBLIOGRAPHY}

Abdur Ra'uf M “Islam and Contemporary Economic Systems” (1976) pp 55-59 in MSA (The Muslim Student's Association of the USA and Canada), Contemporary Aspects of Economic Thinking in Islam Indiana USA.

Abu Saud M Outlines of Islamic Economics Kuwait (1994).

Abu, S A H "The Theory of the Economics of Islam: The Economics of Tawhid and Brotherhood", (1976) in MSA (The Muslim Student's Association of the USA and Canada), Contemporary Aspects of Economic Thinking in Islam Indiana USA 9-54.

Absa Bank Limited, islamicbanking@absa.co.za

Albaraka Bank Limited, http://www.albaraka.co.za/islamicbanking.

Ahmad K Towards a Monetary and Fiscal System of Islam. Islamabad (1981).

Ahmad K (ed) Studies in Islamic Economics Jeddah (1980).

32 These banking services are offered by First National Bank Limited (https://www.fnb.co.za/personal/ transact/chequeaccounts/islamicfinance.html), Absa Bank Limited (islamicbanking@absa.co.za) and Albaraka Bank Limited (http://www.albaraka.co.za/islamicbanking).

33 Stanlib Asset Management, http://www.stanlib.com/; Futuregrowth Asset Management, http://www. futuregrowth.co.za/; Oasis Group Holdings, http://www.oasis.co.za/; Fraters Asset Management (Pty) Ltd, http://www.fraters.co.za/.

34 Zakat Trust is an initiative to collect Zakat and Sadaqah and distribute it to fund Islamic activities and initiatives. 
Ahmad K "EconomicDevelopment in an Islamic Framework" 171-188, in Ahmad K (ed) pp. Studies in Islamic Economics Jeddah (1980).

Ahmad K Islam - Its Meaning and Message London (1975).

Ahmad S M Social Justice in Islam Lahore (1975).

Ahmad S M "Man and Money" pp 217-244 in Islamic Studies (September) 1970 Islamabad (1970).

Ahmad Z "Distributive Justice and Fiscal and Monetary Economics in Islam" pp 311-340 in Ariff M (ed) Monetary and Fiscal Economics of Islam Jeddah (1982).

Badawi M A Z "Zakat and Social Justice" in Islamic Council of Europe (1979) The Muslim World and the Future Economic Order London.

Chapra M U The Economic System of Islam - A Discussion of its Goals and Nature London (1979).

De Villiers S A People's Government The People's Voice. Cape Town, South Africa (2001)

First National Bank Limited, https://www.fnb.co.za.

Fraters Asset Management (Pty) Ltd, http://www.fraters.co.za/.

Futuregrowth Asset Management, www.futuregrowth.co.za/

Galbraith K Economics in Perspective London (1987).

Galbraith K The Nature of Mass Poverty London (1979)

Haneef M A Contemporary Islamic Economic Thought Kuala Lumpur (1995).

Hassan A "Social Justice in Islam” pp, in Islamic Studies 1971 Islamabad (1971) 209-219.

Hasanuzzaman S M "The Liability of Partners in the Islamic Shari'ah" pp. 319-341 in Islamic Studies Islamabad (1981).

Iqbal Munawar Islamic Banking and Finance: Current Developments in Theory and Practice (edited by Dr Iqbal Munawar, on behalf of the Steering Committee for the Fourth International Conference on Islamic Economics and Banking held at Loughborough University UK August 13-15, 2000), published by The Islamic Foundation.

Kahf M The Islamic Economy: Analytical Study of the Functioning of the Islamic System Indiana USA (1978).

Kamali M H Principles of Islamic Jurisprudence Karachi Pakistan (1989).

Mannan M A Islamic Economics Theory and Practice Lahore (1982).

Mintjies H Social Justice in Islam Amsterdam (1977).

Mintjies H "The Shariah and Social Justice" al-Mushir (April/June) 99-105 (1977).

Mische G Toward a Humane World Order New York (1977).

Muslehuddin M Banking and Islamic Law Karachi.

Naqvi S N H Ethics and Economics: An Islamic Synthesis United Kingdom (1981) 
Naqvi S N H 1981 "Economics of Human Rights: An Islamic Perspective" 31-51 in Hamdard Islamicus Karachi Pakistan (1981).

Oasis Group Holdings, http://www.oasis.co.za/

Patel M A Mudarabah Karachi Pakistan (1981).

Rahman A Economic Doctrines of Islam Lahore (1975)

Ramadan S Islamic Law London (1970).

Sakr M A "The Role of the State in the Economic System of Islam" in Islam and a New International Economic Order: The Social Dimension Geneva (1980) 103-110.

Saleh Nabil A Unlawful Gain And Legitimate Profit in Islamic Law Second edition Graham \& Trotman 1980.

Schumacher E F Small is Beautiful: Economics as if people martered London (1973).

Siba'I M Some Glittering Aspects of the Islamic Civilisation Kuwait (1989).

Sidddiqi S A. Public Financing in Islam Ashraf press Lahore (1948).

Stanlib Asset Management, http://www.stanlib.com/

Wilczynski J Comparative Monetary Economics New York: Oxford University Press London Macmillian Press 1978 London (1978).

Wohlers-Scharf T Arab and Islamic Banks: New Business Partners for Developing Countries.

Yusuf S M Economic Justice in Islam Kitab Bhavan New Delhi (1988).

Zaman SM (Syed Muhammad) Economic Functions of an islamic state: The early experience islamic economic studies Leigeste Islamic Foundations (1990)

Zarqa M A "Stability in an Interest-Free Islamic Economy: A Note", 181-188 in Pakistan Journal of Applied Economics (Winter) (1983) 181-188.

Zarqa M A 1982 "Capital Allocation Efficiency and Growth in an Interest-Free Islamic Economy” pp. 43-55 in Journal of Economics and Administration (November) 1982. Jeddah.

Zarqa M A Islamic Economics: An Approach to Human Welfare 3-18, in Ahmad K (ed) pp Studies in Islamic Economics Jeddah (1980) 